\title{
EFFECT OF FREEZE STORAGE ON THE QUALITY OF LAMB MEAT TREATED WITH TOMATO PEEL AND SUMAC EXTRACTS
}

\author{
Mead W. Sadallah ${ }^{1}$ \\ Thamer A. Khalil ${ }^{1}$ \\ ${ }^{1}$ Food sciences Dept./College of Agriculture and Forestry/University of Mosul \\ E-mail: khalilthamer5@gmail.com
}

\begin{abstract}
The study was conducted to investigate the influence of natural antioxidants extracted from tomato (Solanum lycopersicum) peel extract (TPE) and sumac (Rhus coriaria) extract (SE) on the quality of lamb meat stored for (6) months at freezestorage $\left(-18{ }^{\circ} \mathrm{C}\right)$. Treated samples (TS) with these extracts showed a significant values $(\mathrm{p}<0.05)$ of drip loss and water holding capacity (WHC) compared to untreated samples (UTS). The UTS demonstrated a significant increase $(\mathrm{p} \leq 0.05)$ of cooking loss values compared to TS. Peroxide values (POVs) have been decreased steadily with TS until 2 months of storage, unlike the POVs of UTS were ongoing increase until the end of storage, however no POV significant differences were obtained through the storage period. TS with TPE and SE have continuously showed less volatile base nitrogen values $(\mathrm{VBNs})(\mathrm{p} \leq 0.05)$ compared to UTS. Free fatty acid values (FFAs) showed little differences within the first 3 months of storage for UTS and TS, however, after the 3 months of storage, FA of UTS were significantly increased $(\mathrm{p} \leq 0.05)$ by the end of storage period.
\end{abstract}

Keywords: peroxide value, sumac, lamb meat, quality

Received: 22/2/2021, Accepted: 30/3/2021

\section{INTRODUCTION}

Sheep are among the animals that have great importance in the Iraqi economy, as they supply the local market with large quantities of red meat. Sheep are one of the main sources of red meat of the desired quality in Iraq for its palatability and preference by the consumer compared to other meat, as its numbers reached $(6,900)$ thousand heads and its annual contribution to the production of red meat was estimated at 30,930 tons (FAO, 2000). In a study by Raes et al. (2004), it was found that lamb meat is ideal in containing long-chain polyunsaturated fatty acids compared to those found in beef, and this can be concluded that lamb is a good source for humans.

The juiciness, along with the tenderness of the meat, are of the main factors affecting consumer acceptability when consuming the meat (Kosar et al., 2006). It is evaluated in various ways, either subjectively (by consumption) or instrumentally, to measure the ability of meat to hold water. As with other organoleptic properties, keeping lean meats in the presence of oxygen, generally results in lower quality compared to anaerobic packaging, which increases the shelf life (Aaslyng et al., 2010).

Moeller et al. (2010) showed that the values of tenderness and juiciness were highly related to its $\mathrm{pH}$ and to a lesser extent to the temperature used in the cooking process.

Fats play an important functional part in foods, as they affect the productivity of texture and cooking in moisture retention ability (Pizzale et al., 2002). However, 
due to fat oxidation during storage, the flavor, color, texture and nutritional properties of the food are usually reduced (Eriksson, 1982). Fat oxidation can severely reduce the quality of food, because it can lead to unacceptable quality and loss of nutritional value. In addition, oxidation can cause health problems, such as atherosclerosis and cancer (Bashash et al., 2014).

Freezing technology can lower the temperature of the food product below the freezing point, thereby extending the shelf life of the food (Mahmoud et al., 2017) and to preserve its fresh properties (Musa, 2003). It is necessary to use the appropriate method of storing food when it is harvested and transported over long distances (Jeremiah, 2004). The method of freezing food has been widely used due to its great advantages, including preserving its flavor, organoleptic properties, and inhibiting bacterial growth (Masuda et al., 2001). Several freezing methods are used in food, and the standard freezing temperature used is $\left(-18^{\circ} \mathrm{C}\right)$ (Farouk et al., 2004). However, conventional freezing will cause some problems, making the quality of frozen food easily degraded, especially when large ice crystals are formed, which will lead to a decrease in quality parameters. (Musa, 2003; and Zhang et al., 2006). It is found that the shape and size of ice crystals depends on the rate of freezing, so it is necessary to form ice crystals both outside and inside the cell quickly to prevent cell damage (Masuda et al., 2001).

There are internal factors (such as natural antioxidants associated with animal feeding, spices, age, etc.) in the muscles of the body to prevent fat oxidation (Sallam et al.,2004). Antioxidants are usually added to food to prevent oxidation chain reactions in the formation of free radicals, and they function by inhibiting the delayed initiation and propagation steps of initiating the reaction and terminating oxidation. (Bursal and Koksal, 2010; Shan et al., 2005; and Surh, 2002). Natural antioxidants obtained from natural sources are among the substances that have increased circulation in food processing, as the market for food products demands the addition of natural antioxidants that are free of artificial additives and have the ability to reduce oxidation processes in meat and its products (Lawrie, 1998). It was found that many herbs and spices have antioxidant effects on foodstuffs, of which they contain phenols that have an inhibitory effect on oxidation (Shan et al., 2005; and Sen et al., 2014). Upon oxidative stress reactions, the antioxidants will interact with free and non-free radicals to initiate defense mechanisms to protect all compounds inside or outside cells. Due to the increasing demand for natural foods in food processing, it is considered to add natural antioxidants to various foods to delay the oxidative decomposition of fats, improve the quality and nutritional value of fats, and replace them with synthetic antioxidants that have negative effects on human health (Fasseas et al., 2007; Camo et al., 2008; and Yang et al., 2013). The presence of antioxidants in the diet has a beneficial effect on human health, because it can protect biologically important cellular components (such as DNA, proteins and cell lipids) from the attack of reactive oxygen species (ROS (Surh, 2002). Synthetic antioxidants have been used to delay or reduce the oxidative degradation of food, such as butylated hydroxyanisole (BHA), butylated hydroxytoluene (BHT) and tert-butyl hydroquinone (TBHQ) (Fasseas et al., 2007), but they were not desired by the majority of consumers due to their pathogenicity to cause carcinogenicity (Altmann et al., 1986; and Wojdylo et al., 2007). Thus, the advantages of natural antioxidants 
in foods prompted consumers to prefer them for their safe use in foods. Various herbs and spices and their extracts are added to various foods to improve their sensory properties and extend their shelf life (Shan et al., 2005). According to reports, herbs of the Lamiaceae family, especially oregano (Origanum vulgare), rosemary (Rosmarinus officinalis) and sage (Salvia officinalis) have significant antioxidant capacity (Su et al., 2007; Yang et al., 2013). Many herbs and spices and their extracts have antioxidant effects (Zheng and Wang, 2001). Tomatoes are one of the most popular plant sources on earth and an important part of many foods. Tomatoes and tomato products, such as tomato juice, tomato sauce, and tomato soup are usually consumed (Clinton, 1998). Tomatoes contain hydrophilic antioxidants such as ascorbic acid and phenolic compounds such as caffeic acid and quercetin (Van Esch, 1986). Ascorbic acid and phenolic compounds can be considered as the main contributors to hydrophilic antioxidant activity (Arnao et al., 2001), and these compounds are affected by many factors, such as maturity, temperature, variety, and storage atmosphere (Giovanelli and Paradiso, 2002; Hart and Scott, 1995). On the other hand, Sumac (Rhus coriaria) has economic importance due to its increasing use in the food, cosmetics, pharmaceutical, coloring or food preservation industries and veterinary practices (Koohmaraie et al., 2002). The chemical composition of sumac (Rhus coriaria) consists of hydrolysable tannins, which are the highest in sumac fruits, followed by flavonoids, of which this confirms the ability of sumac to contain antioxidants (Ardalani et al., 2016). Other research indicated that the antioxidant activity of sumac extract may be due to a polyphenol compound (Nerin et al., 2006). Sumac is traditionally used as a table spice, and it is recommended for adjusting blood lipid content in diabetics, and it has been indicated that its fruit has antioxidant properties (Giancarlo et al., 2006; and Kumar et al., 2015). Al-Muwaly et al., (2010) found that Iraqi sumac extracted by water and alcohol methods contains a large amount of phenols and flavonoids which have a high scavenging ability for oxidation, because they are resistant to ROS. The purpose of this research is to study the natural antioxidants present in tomato peel and sumac fruits to maintain the characteristics of lamb meat under frozen storage conditions at $\left(-18^{\circ} \mathrm{C}\right)$.

\section{Experimental samples}

\section{MATERIALS AND METHODS}

Local lamb ribs of 6 month old were bought from the local market. After trimming the visible fat and connective tissue, the meat was cut into $3 \times 10 \times 3 \mathrm{~cm}^{3}$. The fresh meat was divided by 6 groups of 3 sample each used for freezing study and 2 samples being used for fresh meat properties. After sample being perforated through different sample sites, the samples were dipped in sumac and tomato rind powder extracts for 4 hours. The meat samples were then vacuum packaged with poly-nylon pouches. The samples were then conditioned in a refrigerator at $2^{\circ} \mathrm{C}$, and then frozen in a freezer (Hitache, Ltd Japanese) at $\left(-18^{\circ} \mathrm{C}\right)$ for $(6)$ months. One sample in each group was inserted with a thermocouple (Elitech Tayp, China) at the geometric center of the sample. During freezing, the temperature of the sample is recorded through the connected thermocouple. The phase transition time is defined by the time from the initial freezing point $-1.2^{\circ} \mathrm{C}$ to $-5^{\circ} \mathrm{C}$ of the geometric center of the sample. After each month of storage, the frozen samples were thawed in a refrigerator at $4^{\circ} \mathrm{C}$ until the 
core temperature of the meat reached $0^{\circ} \mathrm{C}$. All chemicals used in this study are of analytical grade. The thawed samples were tested for drip loss, cooking loss, water holding capacity (WHC), peroxide value (POV), free fatty acid (FFA) and volatile basic nitrogen (VBN).

\section{Drip loss}

Drip loss is calculated as a percentage of weight loss.

$\operatorname{drip} \operatorname{loss}(\%)=\frac{\mathrm{w} 1-\mathrm{w} 2}{\mathrm{w} 1} \times 100$

Where $\mathrm{w} 1$ is the weight of the sample before freezing (gm), and w2 is the weight of the sample after thawing (gm) (Choi et al.,2018).

\section{Water holding capacity (WHC)}

After thawing, 1 gram of minced meat sample was put into a test tube, wrapped it in a metal clip and suspend it in the test tube, and then placed it in a $3000 \mathrm{xg}$ centrifuge (Nuve, J2-21, Turkey) for 10 minutes. The WHC of the sample is calculated as the ratio of the water remaining after centrifugation to the initial water content of the sample as follows:

WHC $(100)=\frac{\mathrm{w} 2}{\mathrm{w} 1} \times 100$

Where w1 is the water amount of the sample before centrifugation, and w2 is the difference in the water amount of the sample after centrifugation (Rahman et al., 2015).

\section{Cooking loss}

The meat sample was put in a polyethylene bag, sealed it under vacuum, and cooked it at $80^{\circ} \mathrm{C}$ for 30 minutes. The sample was then placed at room temperature for 30 minutes. The cooking loss is calculated as follows:

cooking $\operatorname{loss}(\%)=\frac{\mathrm{w} 1-\mathrm{w} 2}{\mathrm{w} 1} \times 100$

Where w1 and w2 are the weight of the sample before cooking the weight of the sample after cooking respectively (Rahman et al., 2015).

\section{Volatile base nitrogen (VBN)}

This test is used to measure meat tenderness and the degree of spoilage due to microbial contamination. The total volatile basic nitrogen (VBN) is determined by micro-diffusion method (Conway, 1950). The method is to take 5 grams of meat samples, put them in a plastic bag containing $20 \mathrm{~mL}$ of distilled water, shaken for 3 minutes, then filtered the sample with Whatman No. 1 filter paper. One $\mathrm{mL}$ of the filtrate was put on the outer part of the Conway dish. A mixture of $1 \mathrm{~mL}$ of $0.01 \mathrm{~N}$ Boric acid $\left(\mathrm{H}_{3} \mathrm{BO}_{3}\right)$ and $100 \mu \mathrm{L}$ of Conway solution $(0.066 \%$ methyl red: $0.066 \%$ bromocresol green, 1:1 using $99.99 \%$ alcohol as solvent) as an indicator were added to the inner part of the Conway dish. Then the Conway unit was immediately closed after adding $1 \mathrm{~mL}$ of $\mathrm{K}_{2} \mathrm{CO}_{3}(50 \%)$ to the outer side of the dish. The dish was incubated at $\left(37{ }^{\circ} \mathrm{C}\right)$ for $(2)$ hours. VBN was measured by titrating with $(0.02 \mathrm{~N})$ $\mathrm{H}_{2} \mathrm{SO}_{4}$ of the inner part of the Conway dish. A blank test was conducted following the same process without adding sample. 
$\operatorname{VBN}(\mathrm{mg} \%)=\frac{14.007 \times(\mathrm{A}-\mathrm{B}) \times \mathrm{F} \times 100 \mathrm{xC}}{\mathrm{S}}$

Where A is the titer of the sample $(\mathrm{mL}), \mathrm{B}$ is the titer of the blank $(\mathrm{mL}), \mathrm{F}$ is the normality of $\mathrm{H} 2 \mathrm{SO} 4(0.02 \mathrm{~N}), \mathrm{S}$ is the sample weight $(\mathrm{gm})$, and $\mathrm{C}$ is the dilution rate. Peroxide value (POV)

POV is estimated by the method of Sallam et al., (2004).Five meat samples were put into $(250) \mathrm{mL}$ glass stopper flasks, then heated in a $\left(60^{\circ} \mathrm{C}\right)$ water bath for $(3)$ minutes to melt the fat. After adding (30) $\mathrm{mL}$ of a mixture of acetic acid and chloroform $(2: 3 \mathrm{v} / \mathrm{v})$ to dissolve the fat, the flasks were shaked for (3) minutes. The mixture was filtered with filter paper Whatman No. 1 to remove meat residue. $0.5 \mathrm{~mL}$ saturated potassium iodide solution was added to the filtrate, while adding starch solution as an indicator. Titration was pursued with sodium thiosulfate standard solution. POV is calculated by the following equation and expressed as milliequivalent of $\mathrm{O}_{2}$ peroxide per kilogram of sample (meq $\mathrm{O}_{2} / \mathrm{kg}$ ):

$\mathrm{POV}\left(\right.$ meq $\left.\mathrm{O}_{2} / \mathrm{kg}\right)=\{(\mathrm{S} \times \mathrm{N}) / \mathrm{W}\} \times 100$

Where $\mathrm{S}$ is the titration volume $(\mathrm{ml}), \mathrm{N}$ is the standard solution of sodium thiosulfate solution $(0.01 \mathrm{~N})$, and $\mathrm{W}$ is the sample weight $(\mathrm{gm})$.

\section{Free fatty acids (FFA)}

The method of Rukunudin et al. (1998) was used to determine FFA value. The meat sample of $5 \mathrm{gm}$ was mixed with $30 \mathrm{~mL}$ of chloroform in a mixer for (1) minute. The mix was filtered with a whatman No.1 to remove meat residue from leachate. 5 drops of $1 \%$ ethanolic phenonphthalein are added to the filtrate with a solution of $(0.01 \mathrm{~N})$ ethanolic potassium hydroxide $(\mathrm{KOH})$. The amount of free fatty acids is estimated as follows:

$$
\mathrm{FFA}=\frac{\mathrm{mL} \text { of titration } \times \mathrm{KOH} \mathrm{N} \times 28.2}{\text { gm of sample }}
$$

\section{Tomato peel extract}

Local fresh tomatoes were purchased from the local market. After washing with tap water, they were mixed in an electric mixer and filtered through cheesecloth to separate the skin and seeds (precipitate) from the tomato juice. The precipitate was then dried in an air dryer (Brabender, Germany) at $\left(50^{\circ} \mathrm{C}\right)$ until a moisture content of $(5 \%)$ was reached. The dried material is ground in a laboratory grinder (Silver Crest, Model :223fs, China) to obtain fine particles of tomato peel powder. A solution of $(10 \%)$ tomato peel powder was prepared with distilled water and used to soak meat samples (Kim and Chin, 2013).

\section{Sumac extract}

Sumac extract was prepared using the method of Al-Muwaly et al. (2013). The sumac fruits were washed with tab water and dried at a temperature of $\left(50{ }^{\circ} \mathrm{C}\right)$ for $(2)$ hours. Dried sumac fruits were then grinded with a laboratory grinder and a solution of grinded sumac and distilled water was prepared at a ratio of $(4.2 \mathrm{~g} / 100 \mathrm{~mL})$. Then the meat samples were soaked in the sumac solution for (2) hours.

\section{STATISTICAL ANALYSIS}

The data was analyzed according to Complete Randomized Design using Duncan Test among the treatments. 


\section{Drip loss}

\section{RESULTS AND DISCUSSION}

The initial drip loss of fresh lamb meat was $(19.65 \mathrm{~mL} / 100 \mathrm{gm})$. Although the drip loss was increased for all UTS and TS with TPE or SE, but it showed higher increase $(\mathrm{p} \leq 0.05)$ with the UTS than TPE and SE at the end of storage period (6 months), as 40.57, 32.42, and $29.90 \mathrm{~mL} / 100$ gm respectively (Fig. 1).

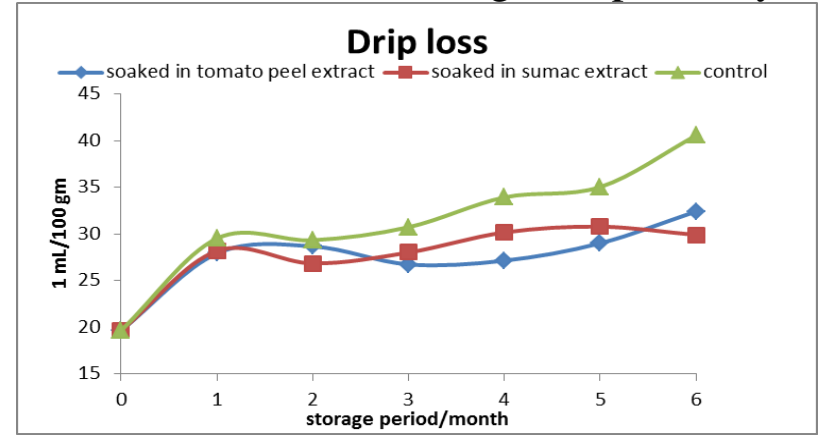

Figure (1): The drip loss (mL/100gm) of frozen lamb meat soaked in tomato peel and sumac extracts compared with untreated samples (control) stored at $\left(-18{ }^{\circ} \mathrm{C}\right)$ for $(6)$ months.

Drip loss is in going process involving the transfer of water from myofibrils to the extracellular space of which it can be higher with decreasing the $\mathrm{pH}$ values of meat (Tayler, 2004). Therefore, within the first 4 month of storage, it can be noticed that samples treated with SE (of higher $\mathrm{pH}$ ) showed a higher $(\mathrm{p} \leq 0.05$ ) of samples treated with TPE (of lower $\mathrm{pH}$ ). On other hand, the lower $\mathrm{pH}$ of muscle proteins, the lower their ability to bind water (den Hertog-Meischke et al., 1997). Further, Lawrie (1985) indicated that meat freshness is high when the $\mathrm{pH}$ of a high value leading to high moisture content and water retention capacity in muscle proteins.

\section{WHC}

The WHC of meat is defined as the affinity with meat to maintain its own moisture during processing, and is considered one of the important indicators of quality, such as eating quality, juiciness, tenderness, and cooking loss (Choi et al., 2018). The initial WHC of fresh sample was $(55.33 \%)$. Frozen lamb of treated and untreated samples showed a significant decrease $(\mathrm{p} \leq 0.05)$ during the storage period of 6 months. Comparing with UTS, the initially soaked samples in either TPE or SE have had a higher WHC $(\mathrm{p} \leq 0.05)$ after the first month of storage (Fig. 2). Although lamb samples stored at $\left(-18^{\circ} \mathrm{C}\right)$ showed a gradual decrease in the continuous storage period of WHC, it showed a significant decrease $(\mathrm{p}<0.05)$ after $(3)$ months of storage in all WHC values. These results were coincided with those obtained by Choi et al. (2018). However, Das et al. (2011) showed that adding curry leaves to minced meat did not significantly affect WHC, but it was observed that WHC was significantly reduced in untreated meat samples. 


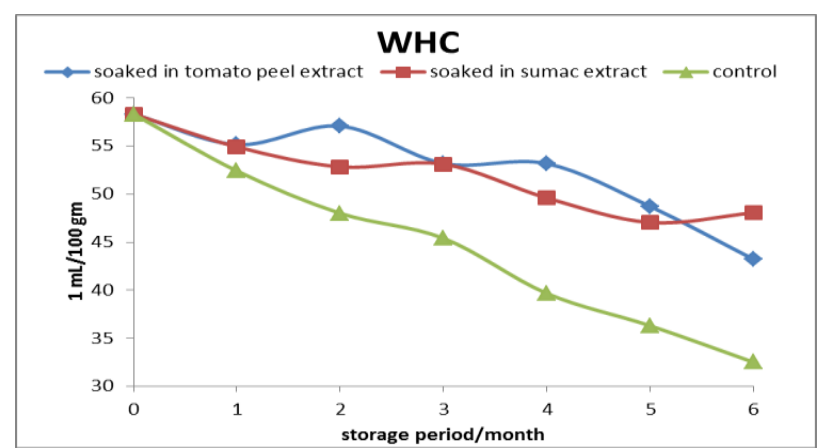

Figure (2): The water holding capacity (WHC) $(\mathrm{mL} / 100 \mathrm{gm})$ of frozen lamb meat soaked in tomato peel and sumac extracts compared with untreated samples (control) stored at ($18{ }^{\circ} \mathrm{C}$ ) for (6) months.

It is speculated that the presence of natural antioxidants in meat products will reduce the percentage of WHC or have a high water retention capacity (Vallverdú-Queralt et al., 2011; and Mohmoud et al., 2017). However, the effect of antioxidants on the hydrolysis of meat protein has been studied by increasing the hydrolysate of short peptides, which may be the reason for the reduction of WHC value (Kim, et al., 2001; Zhang, et al., 2010; and Tounkara, et al., 2013)

\section{Cooking loss}

Figure 3 shows the effect of freezing storage at $\left(-18^{\circ} \mathrm{C}\right)$ for $(6)$ months on cooking loss of UTS and TS of lamb meat with soaking in TPE or SE.

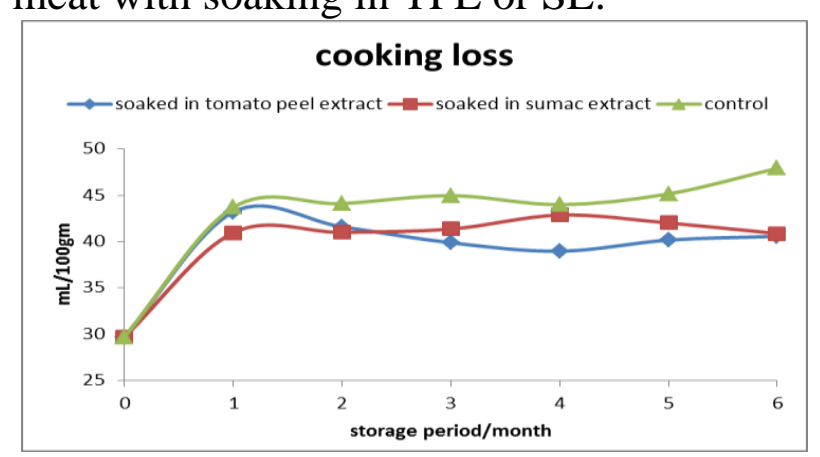

Figure (3): The cooking loss (mL/100 gm) of frozen lamb meat soaked in tomato peel and sumac extracts compared with untreated samples (control) stored at $\left(-18{ }^{\circ} \mathrm{C}\right)$ for $(6)$ months.

After the first month of storage, the cooking loss of all the lamb samples studied increased significantly ( $\mathrm{p} \leq 0.05$ ), which were $43.70,43.20$, and $40.26 \mathrm{~mL} / 100 \mathrm{gm}$ for UTS and TS with TPE and SE respectively. During the continuous storage period, the reduction of the cooking loss value of all samples was small, although the cooking loss value of UTS at the end of the storage period was significantly higher $(\mathrm{p} \leq 0.05)$ than that of TS. Meat samples treated with certain plant extracts can improve cooking loss, thereby combining water and fat (Rinaudo, 2006). In contrast with the work of Choi et al. (2018) who examined the freezing temperature of $\left(-18^{\circ} \mathrm{C}\right)$ of lamb meat stored for (5) months, they reported higher cooking loss values than the results obtained in this study when TPE and SE were experimented.

\section{POV}

POV of fresh lamb meat was (0.94) meq $\mathrm{O}_{2} / \mathrm{kg}$. POVs have been decreased steadily with treated lamb meat samples when TPE and SE were used until 2 months of freezing storage at 
$\left(-18^{\circ} \mathrm{C}\right)$, as $(0.80)$ and $(0.83)$ meq $\mathrm{O}_{2} / \mathrm{kg}$ respectively, then they were kept increasing to the end of storage period (6 months), unlike the POVs of UTS were ongoing increase until the end of storage period (Fig. 4).

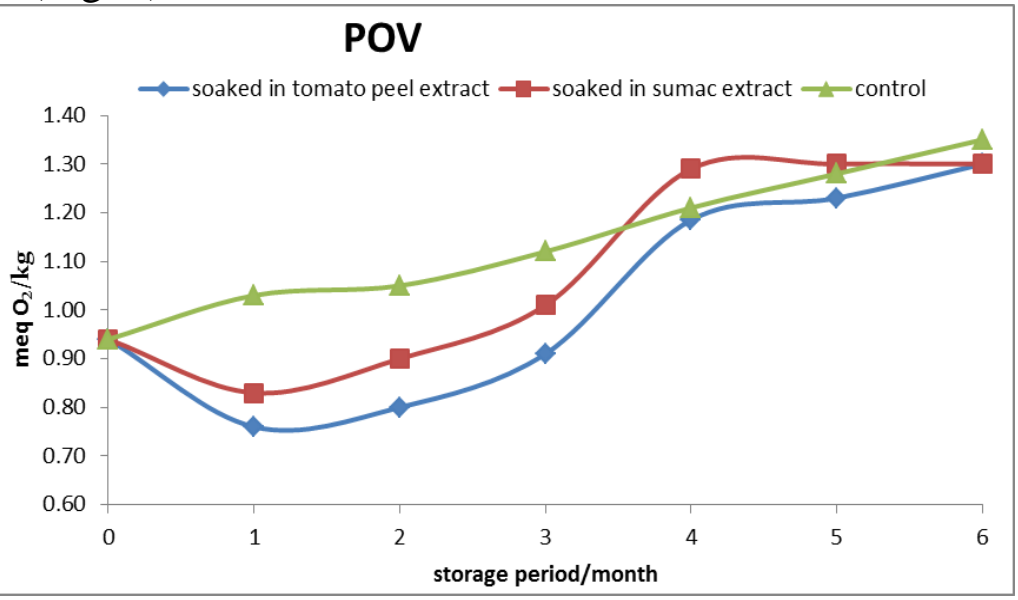

Figure (3): POVs of frozen lamb meat soaked in tomato peel and sumac extracts compared with untreated samples (control) stored at $\left(-18{ }^{\circ} \mathrm{C}\right)$ for $(6)$ months.

Both untreated and treated lamb meat samples with TPE and SE showed the same POV of (1.3) meq $\mathrm{O}_{2} / \mathrm{kg}$ at the end of 6 months storage at $\left(-18^{\circ} \mathrm{C}\right)$. However, in the first three months of storage, the POV difference of TS using TPE or SE is lower than that of the UTS. As mentioned by Masuda et al. (2001) and Kumar et al. (2015) natural antioxidants can donate hydrogen free radicals to pair with other available free radicals, and inhibit the propagation reaction during the entire lipid oxidation process. This can be accrued to a certain extent, until all the hydrogen radicals of the endogenous antioxidants in the lamb meat sample and the natural antioxidants present in TPE and SE are used up within (2-3) months of storage at $\left(-18^{\circ} \mathrm{C}\right)$, as shown in Figure 3.

\section{VBN}

It is well known that the increase in VBN is related to the reaction of microbial spoilage. Initially, the VBN value of fresh lamb was a VBN (14.07) mg/100 gm. Although UTS and TS using TPE or SE followed the same increasing trend of VBN value during the entire (6) months of storage at $\left(-18{ }^{\circ} \mathrm{C}\right)$, both TS with these extracts have continuously shown significantly $(\mathrm{p} \leq 0.05)$ fewer VBN values compared to UTS (Fig. 4).

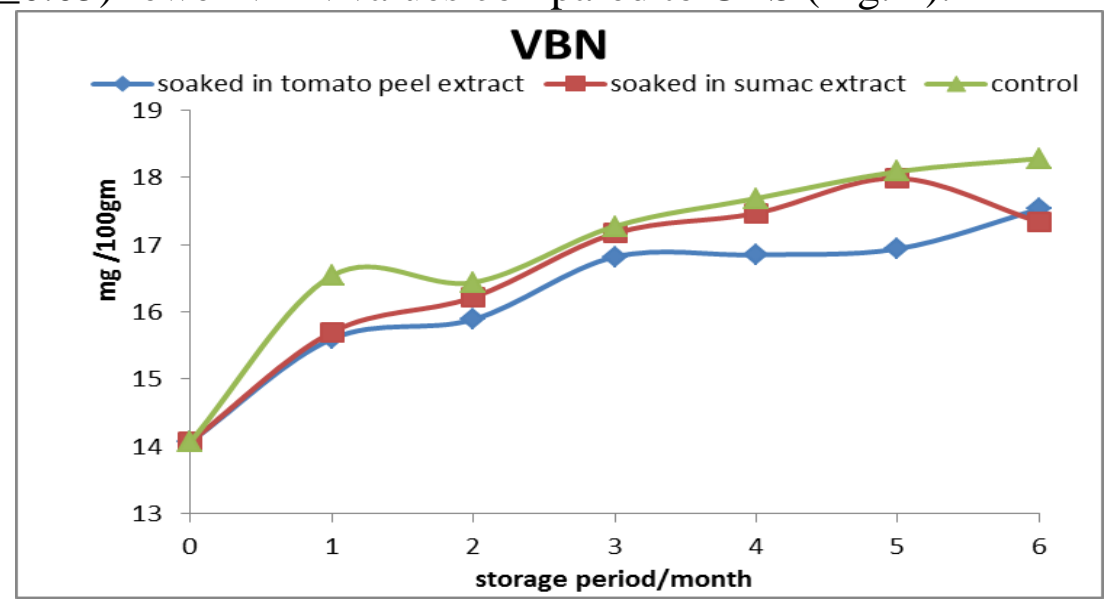

Figure (4): VBN values of frozen lamb meat soaked in tomato peel and sumac extracts compared with untreated samples (control) stored at $\left(-18{ }^{\circ} \mathrm{C}\right)$ for $(6)$ months. 
Although at the end of storage at $\left(-18^{\circ} \mathrm{C}\right)$ for $(6)$ months of UTS and TS with TPE and SE have had VBN values of $18.28,17.53$, and $17.34 \mathrm{mg} / 100 \mathrm{gm}$ respectively, these values were lower than the spoiled level (35 mg/100 gm) suggested by Connell (1990).

\section{FFA}

Generally, FFA is formed from lipids. They are not only the products of enzymatic degradation, but also the microbial degradation of lipids. FFA provides ideas about the stability of lipids during storage. The initial FFA value of fresh lamb is $1.09 \%$. During the first three months of storage of untreated and treated lamb meat samples at $\left(-18^{\circ} \mathrm{C}\right)$, the FFA value showed no significant difference ( $\mathrm{p} \leq 0.05)$ (Fig. 5).

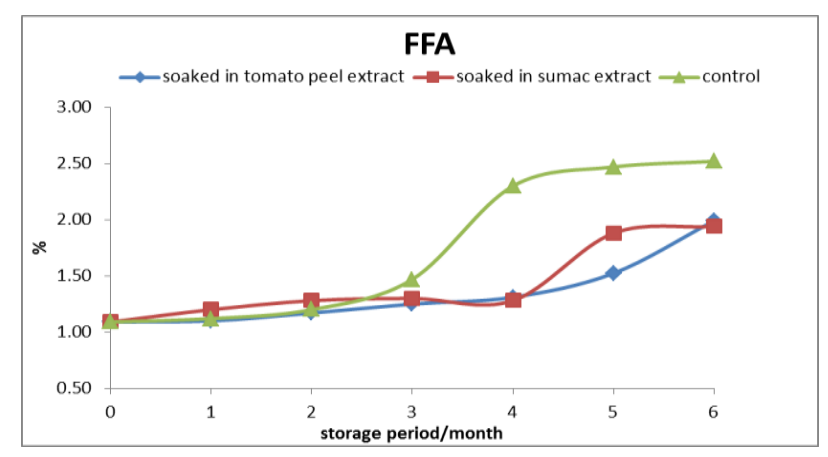

Figure (5): FFA values of frozen lamb meat soaked in tomato peel and sumac extracts compared with untreated samples (control) stored at $\left(-18^{\circ} \mathrm{C}\right)$ for $(6)$ months.

After 3 months of storage at $\left(-18{ }^{\circ} \mathrm{C}\right)$, UTS were significantly increased $(\mathrm{p} \leq 0.05)$ until the end of storage period compared with TS with TPE and SE as the FFA values reached $2.52,1.99$, and $1.94 \%$ respectively. At the end of the storage period of lamb meat samples treated with TPE and SE, the decrease in FFA value may be due to their ability to inactivate enzymatic degradation to form FFA, which is more unstable to the oxidation process of lamb meat. As mentioned earlier, many plant extracts have antioxidant effects on food, and the phenolic substances contained therein have an inhibitory effect on oxidation. (Schwarz, et al., 2001; and Pizzale, et al., 2002).

\section{CONCLUSSION}

Frozen storage at $\left(-18^{\circ} \mathrm{C}\right)$ for $(6)$ months affected the drip loss, WHC, cooking loss, POV, VBN and FFA values of lamb meat. Nevertheless, soaking lamb meat samples in either tomato peel or sumac extracts before freezing storage can improve the quality characteristics of lamb meat in terms of those determined values. Regardless the little differences among the experimented values of lamb meat samples treated with tomato peel or sumac extracts, they showed the same trend when testing the various values studied, but, they have had less influence on the studied values untreated lamb meat samples (control). 
تأثير الخزن بالتجميد في لحم الضأن المعامل بمستخلص قشور الطماطة ومستخلص السماق

$$
\begin{aligned}
& \text { ميعاد وليد سعدالله ثامر عبدالقادر خليل } \\
& \text { قسم علوم الأغذية/ كلية الزراعة والغابات/ جامعة الموصل } \\
& \text { E-mail: khalilthamer5@gmail.com }
\end{aligned}
$$

\begin{abstract}
الخلاصة
أجريت هذه الدراسة لمعرفة تأثير مضادات الأكسة الطبيعية المستخلصة من قشور الطماطة Solanum)

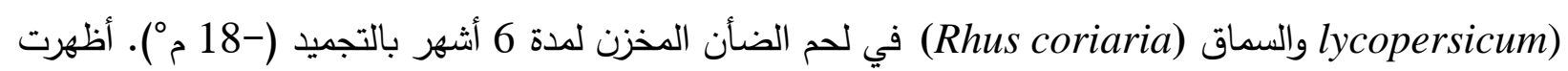
عينات لحم الضأن المعاملة بهذان المستخلصين قيمًا منخفضة (p<0.05) لفقد العصارة وفي قدرة الاحتفاظ بالماء مقارنةً بالعينات غير المعاملة. كانت عينات اللحم غير المعاملة بالمستخلصين أعلى (p<0.05) في قيم فقد الطهي مقارنة بالعينات المعاملة بالمستخلص. انخفضت قيم البيروكسيد مع العينات المعاملة بالمستخلص حتى مدة شهرين من فترة الخزن، ولكن كانت قيم البيروكسيد لعينات اللحم غير المعاملة مستمرة بالارتفاع حتى نهاية فترة الخزن, بالرغم من عدم وجود فرق معنوي بين قيم البيروكسيد لجميع المعاملات في نهاية مدة الخزن. أظهرت العينات المعاملة بكلا

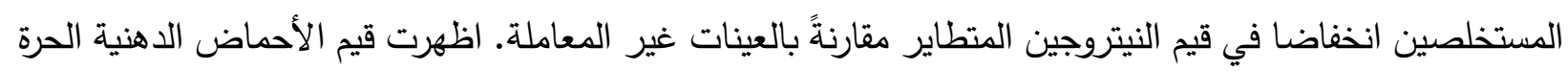
اختلافات طفيفة خلال الأشهر الثلاثة الأولى من فترة الخزن لجميع عينات لحم الضأن، ثم بعد الثلاثة أشهر من فترة الخزن ازدادت قيم الاحماض الدهنية الحرة بشكل معنوي (p<0.05) للعينات غير المعاملة حتى نهاية فترة الخزن.

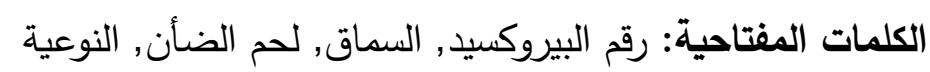

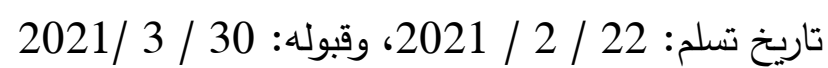

\title{
REFERENCES
}

Aaslyng, M. D., Torngren, M. A., \& Madsen, N. T. (2010). Scandinavian consumer preference for beef steaks packed with or without oxygen. Meat Science, 85(3),519524.

Al-Muwaly, K., Al-Flayeh, K. A., \& Ali, A. A. (2013). Antioxidant and free radical scavenging effects of Iraqi sumac ( Rhus coriaria L.). Baghdad Science Journal, 10(3), 921-933.

Altmann, H. J., Grunow, W., Mohr, U., Richter-Reichhelm, H. B., \& Wester, P. W. (1986). Effects of BHA and related phenols on the forestomach of rats. Food Chemistry and Toxicology, 24,1183-1188.

Ardalani, H., M., Moghadam, Hadipanah, A., Fotovat, F., Azizi, A., \& Soltani, J. (2016). Identification and characterization of chemical composition of Rhus coriaria L. fruit from Hamadan, Western Iran. Journal of Herbal Drug, 6(4), 195-198.

Arnao, M. B., Cano, A., \& Acosta, M. (2001). The hydrophilic and lipophilic contribution to total antioxidant activity. Food Chemistry, 73, 239-244. 
Bashash, M., Zamindar, N., \& Bolandi, M. (2014). Evaluation of antioxidant activities of Iranian sumac $(R$. coriaria L.) fruit and spice extracts with different solvents. Food Measure, 8, 213-217.

Bursal, E. \& Koksal, E. (2010). Evaluation of reducing power and radical scavenging activities of water and ethanol extracts from sumac (Rhus coriaria L.). Food Research International, 44, 2217-2221.

Camo, J., Beltrán, J. A., \& Roncalés, P. (2008). Extension of the display life of lamb with an antioxidant active packaging. Meat Science, 80,1086-1091.

Choi, M., Abduzukhurov, T., Park, D. H., Kim, E. J., \& Hong, G. (2018). Effects of deep freezing temperature for long-term storage on quality characteristics and freshness of lamb meat. Korean Journal of Food Science, 38(5), 959 969.

Clinton, S. K. (1998). Lycopene: chemistry, biology, and implications for human disease. Nutrition Review, 56, 35-51.

Connell, J. J. (1990). Methods of Assessing and Selecting for Quality. In Control of Fish Quality. (3rd ed). Connell, J. J. (ed). Springer, Berlin, Germany. p:122-150.

Conway, E. J. (1950). Microdiffusion Analysis and Volumetric Error, (3rd ed). Crosby Lockwoood and Son Ltd., London. p:156-167.

Das, A. K., Rajkumar, V., \& Dwivedi, D. K. (2011). Antioxidant effect of curry leaf (Murraya koenigii) powder on quality of ground and cooked goat meat. International Food Research Journal, 18(2), 563-569.

den Hertog-Meischke, M. J. A., van Laak, J. L. M., \& Smulders, F. J .M. (1997). The water holding capacity of fresh meat. Veterinary Quality, 175-181.

Eriksson, C. E. (1982). Oxidation of lipids. Food Chemistry, 9: 3-20.

FAO, Food and Agriculture Organization (2000). Said in its 3rd ed. of the "World Watch List for Domestic Animal Diversity" Released Today. PR 00/66.

Farouk, M. M., Wieliczko, K. J., \& Merts, I. (2004). Ultrafast freezing and low storage temperatures are not necessary to maintain the functional properties of manufacturing beef. Meat Science, 66, 171-179.

Fasseas, M. K., Mountzouris, K. C., Tarantilis, P. A., Polissiou, M., \& Zervas, G. (2007). Antioxidant activity in meat treated with oregano and sage essential oils. Food Chemistry, 106,1188-1194.

Giancarlo, S, Rosa, L. M., Nadjafi, F., \& Francesco, M. (2006). Hypoglycaemic activity of two spices extracts: Rhus coriaria L. and Bunium persicum Boiss. Natural product research, 20(9), 882-886.

Giovanelli, G. \& Paradiso, A. (2002). Stability of dried and intermediate moisture tomato pulp during storage. Journal of Agriculture and Food Chemistry, 50, 7277-7281.

Hart, D. J. \& Scott, K. J. (1995). Development and evaluation of an HPLC method for the analysis of carotenoids in foods, and the measurement of the carotenoids content of vegetables and fruits commonly consumed in the UK. Food Chemistry, 54,101-111.

Jeremiah, L. E. (2004). Refrigeration and Freezing Technology: Freezing and Food Quality. In: Jensen WK, Devine C, Dikeman M (eds). Encyclopedia of Meat Sciences, Elsevier BV, Netherlands. 1156-1161.

Kim, H. S. \& Chin, K. B. (2013). Antioxidant activity of tomato powders as affected by water solubility and application to the pork sausages. Korean Journal of Food Science, 33 (2), 170-180. 
Kim, S. K., Byun, H. G., Park, P. J., \& Shahidi, F. (2001). Angiotensin I converting enzyme inhibitory peptides purified from bovine skin gelatin hydrolysates. Journal of Agriculture and Food Chemistry, 49, 2992-2997.

Koohmaraie, M., Kent, M. P., Shackelford, S. D., Veiseth, E., \& Wheeler, T. L. (2002). Meat tenderness and muscle growth: Is there Any relationship? Meat Science, 62, Special Issue S1, 345-352.

Kosar, M., Temellifi, F. B., \& Baser, K. (2006). Antioxidant (Rhus Corairai L) extract. Food Chemistry, 103, 956-959.

Kumar, Y., Yadav, D. N., Ahmad, T., \& Narsaiah, K. (2015). Recent trends in the use of natural antioxidants for meat and meat products. Comprehensive Reviews in Food Science and Food Safety, 14(6), 796-812.

Lawrie, R. A. (1998). Lawrie's Meat Science (6 $6^{\text {th }}$ ed.). Lancaster, PA: Technomic Publishing Inc. p. 189-226.

Leygonie, C., Britz, T. J., \& Hoffman, L. C. (2012). Impact of freezing and thawing on the quality of meat: Review. Meat Science, 91(2), 93-98.

Mahmoud, M. H., Abou-Arab, A. A., \& Abu-Salem, F. M. (2017). Quality characteristics of beef burger as influenced by different levels of orange peel powder. American Journal of Food Technology, 12, 262-270.

Masuda, T., Inaba, Y., \& Takeda, Y. (2001). Antioxidant mechanism of carnosic acid: structural identification of two oxidation products. Journal of Agricultural and Food Chemistry, 49(11), 5560-5565.

Musa, O. (2003). Effect of sumac (Rhus Corairai L.) extracts on the oxidative stability of peanut oil. Journal of Medicinal Food, 6(1), 63-66.

Nerin, C., Tovar, L., Djenane, D., Camo, J., Salafranca, J., Beltrán, J. A., \& Roncales, P. (2006). Stabilization of beef meat by a new active packaging containing natural antioxidants. Journal of Agriculture and Food Chemistry, 52, 5598-5605.

Pizzale L., Bortolomeazzi, R., Vichi, S., Uberegger, E., \& Conte, L. S. (2002). Antioxidant activity of sage (Salvia officinalis and S. fruticosa) and oregano (Origanum onites and $O$. indercedens) extracts related to their phenolic compound content. Journal of the Science of Food and Agriculture, 82, 1645-1651.

Raes, K., De Smet, S., \& Demeyer, D. (2004). Effect of dietary fatty acids on incorporation of long chain polyunsaturated fatty acids and conjugated linoleic acid in lamb, beef and pork meat: A Review. Animal Feed Science Technology, 113,199-221.

Rahman, M. H., Hossain, M. M., Rahman, S. M. E., Amin M. R., \& Deog-Hwan, O. (2015). Evaluation of physicochemical deterioration and lipid oxidation. Korean Journal of Food Science, 35 (6), 772-782.

Rinaudo, M. (2006). Chitin and chitosan: properties and applications. Progress in Polymer Science, 7 (31), 603-632.

Rukunudin, I. H., White, P. J., Bern, C. J., \& Bailey, T. B. (1998). A Modified method for determining free fatty acids from small soybean sample sizes. Journal of American Oil Chemist's Society, 75, 563-568.

Sallam, K. L., Ishioroshi, M., \& Samejima, K. (2004). Antioxidant and antimicrobial effects of garlic in chicken sausage. LWT-Food Science and Technology, 37, 849855.

Schwarz, K., Bertelsen, G., Nissen, L. R., Gardner, P. T., Heinonen, M. I., . Huynh-Ba, A. H, Lambelet, P., McPhail, D., Skibsted, L. H., \& Tijburg, L. (2001). Investigation of 
plant extracts for the protection of processed foods against lipid oxidation. The Journal European Food Research and Technology, 212, 319-328.

Sen, A. R., Naveena, B. M., Muthukumar, M., \& Vaithiyanathan, S. (2014). Colour, myoglobin denaturation and storage stability of raw and cooked mutton chops at different end point cooking temperature. Journal of Food Science Technology, 51(5), 970-975.

Shan, B., Cai, Y. Z., Sun, M., \& Corke, H. (2005). Antioxidant capacity of 26 spice extracts and characterization of their phenolic constituents. Journal of Agriculture and Food Chemistry, 53, 7749-7759.

Su, L., Yin, J. J., Charles, D., Zhou, K., Moore, J., \& Yu, L. (2007). Total phenolic contents, chelating capacities, and radical-scavenging properties of black peppercorn, nutmeg, rosehip, cinnamon and oregano leaf. Food Chemistry, 100, 990997.

Surh, Y. J. (2002). Anti-tumour promoting potential of selected spice ingredients with antioxidative and anti-inflammatory activities: Short Review. Food and Chemical Toxicology, 40: 1091-1097.

Tayler, R. G. (2004). Connective Tissue Structure, Function and Influence on Meat Quality. In Jensen, W. K., Devine, C. \& Dikeman, M. (Eds.) Encyclopedia of Meat Sciences. New York, Elsevier Academic Press.

Tounkara, F., Sodio, B., Amza, T., Wei, Le, G., \& Shi, Y. (2013). Antioxidant effect and water-holding capacity of roselle (Hibiscus sabdariffa L.) seed protein hydrolysates. Advance Journal of Food Science and Technology, 5(6), 752-757.

Vallverdu-Queralt, A., Medina-Remon, A., Martínez-Huélamo, M., Jáuregui, O., AndresLacueva, C., \& Lamuela-Raventos, R. M. (2011). Phenolic profile and hydrophilic antioxidant capacity as chemotaxonomic markers of tomato varieties. Journal of Agricultural and Food Chemistry, 59(8), 3994-4001.

Van Esch, G. J. (1986). Toxicology of tert-butylhydroquinone (TBHQ). Food Chemistry and Toxicology, 24,1063-1065.

Wojdylo, A., Oszmiański, J., \& Czemerys, R. (2007). Antioxidant activity and phenolic compounds in 32 selected herbs. Food Chemistry, 105, 940-949.

Yang, H., Meng, P., Xiong, Y. L., Ma, L., Wang, C., \& Zhu, Y. (2013). Oxidation in HiOxpackaged pork longissimus muscle predisposes myofibrillar and sarcoplasmic proteins to N-nitrosamine formation in nitrite-curing solution. Meat Science, 95(3), 465-471.

Zhang, H., Chen, F., Wang, X., \& Yao, H. Y. (2006). Evaluation of antioxidant activity of parsley (Petroselinum crispum) essential oil and identification of its antioxidant constituents. Food Research International, 39, 833-839.

Zheng, W. \& Wang, S. Y. (2001). Antioxidant activity and phenolic compounds in selected herbs. Journal of the Agricultural and Food Chemistry, 49, 5165-5170. 